\title{
THE ROLE OF AUDIT RESULTS DECISIONS OF THE FINANCIAL AUDITING AGENCY IN RESTORING STATE LOSSES
}

\author{
Joko Sriwidodo, Kristiawanto and Tofik Yanuar \\ Lecturers of Undergraduate and Post Graduate Studies of Law, \\ Faculty of Law, University of Jayabaya, Jakarta, Indonesia.
}

Corresponding Author: joko_sriwidodo@jayabaya.ac.id.

DOI: 10.31364/SCIRJ/v8.i8.2020.P0820XX

http://dx.doi.org/10.31364/SCIRJ/v8.i8.2020.P0820XX

\begin{abstract}
The Supreme Audit Agency (BPK) is a free and independent state institution in Indonesia that has the task to examine the management and responsibility of state finances as provided by the 1945 Constitution of the Republic of Indonesia. This institution has three functions, namely, operational, judicial, and advisory functions. To determine the occurrence of state financial losses, the Supreme Audit Agency (BPK) provides reports on the results of its audits to related institutions including reports of irregularities in state finances, providing reports to the Corruption Eradication Commission, the Police, the Attorney General's Office, to follow up on cases of suspected corruption, money laundering, etc. This study aims at discussing the following questions: (1) what is the State Loss Recovery System in Indonesia? (2) what is the Role of BPK's Audit Result Decisions in Recovering State Losses in Indonesia? The method to examine these research questions is by conducting library research and web-search. The study indicates that the state loss recovery system in Indonesia is solved by internal agencies itself and by outside the court. The internal agency solved this problem by forming a State Loss Settlement Team (TPKN), whilst the outside court is done through by demands for compensation made by the BPK and how to recover state losses through the judiciary, namely through criminal law instruments, administrative law instruments, and civil law instruments. Meanwhile, the role of the BPK audit result decision in recovering state losses can, if a state loss does not have a criminal element, be directly solved by the BPK itself. This same solution is also done by the outside court.
\end{abstract}

Keywords: Supreme Audit Agency; Financial auditing; State Finance; State Losses, Indonesia

\section{INTRODUCTION}

In reaching various modes of irregularities in state finances, the criminal act of corruption is formulated in such a way as to include the act of enriching oneself or another person or a corporation against the law in both formal and material terms. In reaching the mode of irregularity in state finances, the element against the law is also fulfilled. The element against the law (wederechtelijke) can qualify as against both formal and material law. The nature of being against the formal law means that the perpetrator's actions are contrary to formal legal provisions such as laws, government regulations, presidential regulations, ministerial regulations, and others. It is also worth noting that the violated formal regulations do not necessarily contain criminal sanctions. For example, a Presidential Regulation does not contain criminal sanctions, but the violation of these provisions can prove elements against the law. The definition of law (recht) is broader than laws, government regulations, presidential regulations, and others as written law. This is simply because it also contains the meaning of unwritten law such as customs, appropriateness, and morality in society.

Violation of habit, appropriateness, and morality is a nature against material law, which in judicial practice in Indonesia can function positively (as a reason to punish) as happened in the case of R. Sonson Natalegawa (Jurisprudensi MA RI No.275K / Pid / 1983 dated 29 December 1983), and can function negatively (as an excuse to abolish punishment/release) as in the case of Machrus Effendi (MA RI Jurisprudence No.42K / Kr / 1965 dated January 8, 1966). See, Effendi (2005). 
Likewise with the element of enriching oneself or another person or a corporation (Article 2 paragraph (1) of Law No. 31 of 1999 in conjunction with Law No. 20 of 2001) and elements of with the aim to benefit oneself or another person or a corporation" (vide Article 3 of Law No. 31 of 1999 in conjunction with Law No. 20 of 2001), is an alternative element so that the perpetrator of a criminal act of corruption does not need to enjoy the proceeds of the criminal act of corruption by himself because it is sufficient for the perpetrator to enrich others or benefit others (http://www.kejari-jakbar.go.id/index.php/component/k2/item/236permasalahan-seputar-kerugian-keuangan-negara-tinjauan-dari-perspektif-pembuktian-hukum-pidana).

Meanwhile, concerning the element of detrimental to state finances, law enforcement officers indeed collaborate with related agencies, namely the BPK or BPKP, which helps investigators calculate state losses. In the development of BPK and BPKP audits recently, it is evident that the BPK or BPKP audit results have led to an audit against the law which is not a zone of authority. The authority of the BPK or BPKP in conducting audits is in the accounting zone, so there is no need to go far to look for illegal acts or not because that is the authority of the Investigators and Public Prosecutors. In terms of the element of state financial loss, the construction of Article 2 paragraph (1) of Number 31 of 1999 associated with Law Number 1 of 2004 must be viewed comprehensively, by examining the extent to which the relationship between the return of state losses and the illegal actions it has committed. Reimbursement of state losses after the results of the audit conducted by the BPK does not necessarily mean that the BPK does not need to report it to the authorized agency. Thus, any findings of state losses by BPK from the results of the audit it has carried out must be reported to the authorized agency (KPK, Attorney General's Office, POLRI) to see whether the state loss returned is an act against the law or not.

In proving the element of detrimental to state finances, confusion also occurred. Sometimes in judicial practice, it has been proven that the element is detrimental to state finances. However, the element of enriching oneself or another person or a corporation (Article 2 paragraph (1)), or the element of benefiting oneself or another person or a corporation is not proven. This was used as an excuse to acquit suspects of corruption. Such juridical construction errors seem to hinder the law enforcement process. Supposedly, with the proof of the element of state loss, it means that money or state assets have been lost. This ensures that the suspect has enriched himself or another person or a corporation, or the suspect has benefited himself or another person or a corporation, with money or state assets that have been proven missing. Thus, the proof of the element of state financial loss in a trial, it can be said that the element of enriching oneself or another person or a corporation or has benefited themselves or another person or a corporation, has also been proven. If this is not the case, then an illogical juridical construction occurs.

The method of calculating state losses cannot be set in standard to be used as a guide or reference in calculating state losses. This is because the modus operandi, cases of irregularities, and forms of state loss can vary. In carrying out the examination, the examiner can choose the method that is considered the most appropriate. by dividing the concepts or methods of calculating state financial losses, namely:

1. Total Loss (Total Loss). This method calculates state financial losses by means that all amounts paid are stated as state financial losses.

2. Total Loss by Adjustment. The total loss method with adjustments is as in the Total Loss method, only with an upward adjustment. Adjustments are required if the purchased goods must be destroyed and the destruction costs money. State financial losses are not only in the form of expenses for the procurement of these goods, but also the costs required or incurred to destroy these goods.

3. Net Loss In the net loss method, the method is the same as the total loss method. It's just that with a downward adjustment. Net loss is the total loss minus the net value of the goods which are considered to have value. Net value is the difference that is usually obtained minus the salvaging cost.

4. Fair price. In this method of calculating state financial losses, the fair price is the comparison with the realized price. Losses on state finances where the transaction is not fair in the form of the difference between the fair price and the realized price ( Paeh, 2017).

In-Law No. 32/2004 regulates the supervision of regional government administration, which in practice is carried out by internal supervisory officials who are accommodated in the Regional Supervisory Agency (BAWASDA) which is now a Regional Directorate both in Provincial and Regency / City governments. The results of guidance and supervision can be used as material for examination by the Supreme Audit Agency (BPK (Article 221 of Law No. 32 of 2004 on Regional Government). Thus in upholding laws in the regions, especially in the government's efforts to eradicate corruption, it is appropriate for Regional Directorate (BAWASDA) to be involved. In efforts to eradicate corruption from a preventive administrative perspective.

www.scirj.org

(C) 2020, Scientific Research Journal

http://dx.doi.org/10.31364/SCIRJ/v8.i8.2020.P0820XX

This publication is licensed under Creative Commons Attribution CC BY. 
Based on the description above, this paper aims at discussing the following two issues, namely, what is the State Loss Recovery System in Indonesia? and what is the Role of BPK Audit Result Decisions in Recovering State Financial Losses in Indonesia?

\section{LITERATURE REVIEW}

The theory is a guide or guide in determining the objectives and direction of research. To analyze the data collected to answer the above questions, this study uses the theory of Restorative Justice theory, as proposed by Tony Marshall, namely restorative justice. This a process whereby all the parties with a stake in a particular offense come together to resolve collectively how to deal with the aftermath of the offense and its implications for the future (Marshall, 1999). Whereas a restorative state is a process in which all parties involved in a certain crime together seek solutions jointly to find solutions in dealing with events after the occurrence of the crime and how to deal with its implications in the future. In addition, restorative justice emphasizes the notion of crime as an act against individuals or society, not as a form of violation against the state (Sri Widodo, 2014). The use of restorative justice theory is to see that the return of state losses is a preventive effort to return state finances without having to go through a criminal process.

\section{The Supreme Audit Agency}

The Supreme Audit Agency is the oldest state institution in charge of tackling and eradicating the occurrence of criminal acts of corruption compared to corruption eradication agencies in Indonesia compared to the Corruption Eradication Commission (KPK), the Finance and Development Audit Agency (BPKP) or an institution called the Criminal Eradication Team. Corruption (Timtastipikor). The formulation of the Supreme Audit Agency has been established since the unitary state of the Republic of Indonesia and is contained in the 1945 Constitution. In eradicating the culture of corruption in Indonesia, the government has also created institutions, agencies, or commissions whose main function is related to business. - efforts to eradicate corruption. These institutions, agencies, or commissions include the Supreme Court, BPK, KPK, Police, Timtastipikor, KY, BPKP, and the Attorney General's Office, all of which are interrelated and mutually supportive in a system established by the government in carrying out their duties.

As many have written, the origin of the idea for the establishment of the Supreme Audit Agency came from Raad van Rekenkamer during the Dutch East Indies era. Several other countries also establish institutions of this kind to carry out audit functions or as external auditors of the government's financial performance. The audit function associated with this institution is closely related to the oversight function by the parliament. Therefore, the institutional position of the Supreme Audit Agency (BPK) is actually in the realm of legislative power or at least coincides with the oversight function carried out by the DPR. Therefore, the report on the results of the investigation conducted by the BPK must be reported or submitted to the DPR for proper follow-up (Assiddiqie, 2010).

To further strengthen the tasks of the Republic of Indonesia BPK, the provisions governing BPK RI in the 1945 Constitution have been amended. Before the amendments to the BPK RI were only regulated in one paragraph (article 23 paragraph 5) then in the Third Amendment of the 1945 Constitution it was developed into a separate chapter (Chapter VIII-A) with three articles $(23 \mathrm{E}, 23 \mathrm{~F}$, and $23 \mathrm{G})$ and seven paragraphs. To support its duties, BPK RI is supported by a set of laws in the field of State Finance, namely;

a. Law No.17 of 2003 concerning State finances

b. Law No.1 of 2004 concerning State Treasury

c. UU no. 15 of 2004 concerning Audit of Management and Accountability of State Finances.

Furthermore, the position of the BPK is independent of the influence and power of the Government. However, it does not stand on the Government. Furthermore, the results of the BPK examination were notified to the DPR (Sidjabat, 1968). This means that BPK is only obliged to report the results of its examination to the DPR. Thus the BPK is an independent body and is not subordinate to the DPR. The same thing is also found in the working relationship between Algemeene Rekenkamer and the Volksraad.

www.scirj.org

(C) 2020, Scientific Research Journal

http://dx.doi.org/10.31364/SCIRJ/v8.i8.2020.P0820XX

This publication is licensed under Creative Commons Attribution CC BY. 
The position of the BPK is also contained in article 2 which reads: The BPK is a state institution that is free and independent in examining the management and responsibility of State finances (Badan Pemeriksa Keuangan, 2006). In this increasingly strong position and greater authority, Assidiqie (2006) indicates the function of the BPK in essence still consists of three areas, namely:

a. Operative function, namely in the form of examination, supervision, and investigation of control, management, and management of assets over the state.

b. The judicial function, namely in the form of the authority to demand treasury and compensation claims against treasurers and civil servants who are not treasurers who because of their actions violate laws or neglect obligations that cause financial losses and state assets.

c. Advisory function, which provides consideration to the government regarding the management and management of state finances.

In carrying out audit duties, the BPK is authorized to:

a. Determine the objective of the examination, plan, and carry out the examination, determine the time and method of the examination and prepare and present the inspection report.

b. Request information and/or documents that must be provided by every person, organizational unit of the Central Government, Regional Government, and other state institutions.

c. Conduct inspections at the place where money and assets belong to the state, at the place where activities are carried out, bookkeeping and state financial administration, as well as the examination of calculations, letters, evidence, current accounts, accountability and other lists relating to the management of State finances.

d. Determine the types of documents, data, and information regarding the management and responsibility of state finances that must be submitted to the BPK.

e. Establish standards for auditing state finances after consultation with the Central Government / Regional Governments which must be used in auditing the management and accountability of state finances.

f. Establishing a code of ethics and auditing the management and accountability of state finances.

g. Using experts and/or auditors outside the BPK who work for and on behalf of the BPK.

h. Fostering the functional position of the examiner.

i. Provide consideration for Government Accounting Standards.

j. Give consideration to the design of the internal control system of the Central Government / Regional Government.

Furthermore, in terms of settling state / regional losses, the BPK has the authority to assess and/or determine the number of state losses caused by illegal or negligent acts committed by the treasurer, the management of State-Owned Enterprises / RegionalOwned Enterprises, and other institutions or entities. others who carry out the management of State finances and monitor the settlement of state / regional compensation set by the government for non-treasurer civil servants or other officials, imposing state / regional compensation for regional losses, managing BUMN / BUMD, and other institutions or agencies that manage finances the state that has been determined by the BPK and the implementation of the imposition of state / regional compensation which is determined based on a court decision that has the permanent legal force to be notified in writing to the DPR, DPD, and DPRD in accordance with their authority.

In addition, the BPK also has the authority to provide opinions to the DPR, DPD and DPRD, central/regional governments, other state institutions, Bank Indonesia, BUMN, public service agencies, BUMDs, foundations, and other institutions or bodies, which are needed because of their nature. The work of this institution is to provide considerations on the settlement of state/regional losses determined by the Central Government/Regional Government and provides expert information in the judicial process regarding state/regional losses.

\section{State Finance}

www.scirj.org

(C) 2020, Scientific Research Journal

http://dx.doi.org/10.31364/SCIRJ/v8.i8.2020.P0820XX

This publication is licensed under Creative Commons Attribution CC BY. 
State finances are all rights and obligations of the state that can be valued in money, as well as everything in the form of money or goods that can be made the property of the State in connection with the implementation of these rights and obligations. In the explanation of Law Number 17 of 2003 concerning State Finance, it is stated that the approach used in formulating State Finance is in terms of object, subject, process, and objective. From the object side, what is meant by State Finance includes all rights and obligations of the state that can be valued in money, including policies and activities in the fiscal, monetary and management of separated state assets, as well as everything in the form of money, or in the form of goods that can be used as state property in connection with the exercise of these rights and obligations.

From the subject point of view, what is meant by State Finance includes all subjects who own/control the objects as mentioned above, namely: the central government, local governments, state / regional companies, and other agencies related to state finances. From the process side, State Finance includes the entire series of activities related to the management of objects as mentioned above, starting from policy formulation and decision making to accountability. In terms of objectives, State Finance includes all policies, activities and legal relations relating to ownership and/or control of objects as mentioned above in the framework of implementing state governance.

In Article 2 of the Law on State Finance, it is even broader and detailed about what is included in state finances as follows:

a. State assets / regional assets that are managed by themselves or by other parties in the form of money, securities, receivables, goods, and other rights that can be valued in money, including assets that are separated from state / regional companies.

b. The assets of other parties are controlled by the government in the context of carrying out government tasks and/or public interests.

c. The wealth of other parties obtained by using facilities provided by the government.

Along with the implementation of Law no. 32 of 2004 concerning Regional Autonomy and Law No. 33 of 2004 concerning Financial Balance between the Central Government and Regional Governments, there has been a shift in the management of public finances in Indonesia. The shift occurred in relation to the financing of a more decentralized government administration. The management of financial resources has also undergone a shift, many public financial sources are centralized to districts and cities, for the sake of the implementation of autonomous regional households. Optimization of financial management in the regions is intended so that regional governments as administrators of autonomy do not experience fiscal deficits. Therefore, reforms were carried out in all fields including institutional reforms and public sector management reforms, especially those related to public financial management in order to support the creation of good governance. Further reforms were implemented mainly in relation to the following matters.

a. Reform of the financing system (financing reform).

b. Budgeting reform.

c. Accounting system reform (accounting reform).

d. Audit reform.

e. Reform of the regional financial management system (financial management reform). See, Yani (2004).

The demand for reform of the public financial system is intended for transparent management of public money so as to create public accountability. Public financial management reform is related to the need to use a new public financial management module that is in line with the demands of the times. Regional financial reforms relate to changes in the sources of regional financial revenues. The dimensions of regional financial reform are as follows.

a. Changes in regional authority in the use of financial balancing funds.

b. Change in budget management principles.

c. Changes in the principle of using loan funds and deficit spending.

d. Changes in financing strategy (Sulaiman, 2000).

www.scirj.org

(C) 2020, Scientific Research Journal

http://dx.doi.org/10.31364/SCIRJ/v8.i8.2020.P0820XX

This publication is licensed under Creative Commons Attribution CC BY. 
Law 17 of 2003 states that Article 2 of the Law on State Finance regulates the state financial space, namely: The right of the state to collect taxes, issue and circulate money, and make loans; For the country, do general tasks, manage the country and pay third party bills; state revenue; visiting country; regional revenue; visit the area; State assets or regional assets managed by themselves or by other parties consist of money, securities, receivables, goods, and other rights that can be obtained with money, including assets that are regulated in state or regional enterprises; the assets of other parties that are controlled by the government in the framework of implementing governmental duties and in the public interest.

The main rules of State Finances have been published in general principles, which include principles that have long been recognized in the Management of State Finances, namely as follows:

a. Annual Principle provides a budget made by the State which must obtain approval from the legislative body (DPR).

b. The principle of universality (completeness), provides an agreement that is not approved regarding the mixing of state revenues and state transfers.

c. The principle of unity, maintaining the budget from the council, means that all support must be in the budget.

d. The principle of specialization requires that the types provided are in a specific/special line item and be fully provided both qualitatively and quantitatively.

e. The principle of accountability is results-oriented, understands the meaning of each user, is required, and explains the organization's success or overcoming a program for which it is responsible.

f. The principles of professionalism that govern the management of state finances which are managed by professional staff.

g. The principle of proportionality; budget allocation that is implemented in the functions of the ministry/agency in accordance with the level of priority and objectives to be achieved.

h. The principle of openness in the management of state finances requires openness in the discussion, determination, and calculation of budgets as well as the results of supervision by an independent audit institution

i. The principle of a financial audit by a free and independent audit agency gives greater authority to the Supreme Audit Agency to regulate the audit of state finances according to the purpose and independently (http://tongsel.blogspot.com/2016/03/makalahkeuangan-negara.html? $\mathrm{m}=$ ).

There are several problems that are still real in the management of state finances today, namely:

a. The low effectiveness and efficiency of the use of government finances are due to the rampant irrationality of financing state activities.

b. The lack of importance of the priority scale formulated in the process of managing state finances leads to a waste of public resources.

c. Demanding financial management reform is one that causes more leakage and irregularities, such as those caused by the practice of Collusion, Corruption, and Nepotism.

d. Low government professionalism in managing public budgets (http://tongsel.blogspot.com/2016/03/makalah-keuangannegara.html? $\mathrm{m}=1$, )

\section{State Losses}

State losses according to Article 1 number 15 Law no. 15 of 2006 concerning the Supreme Audit Agency and also according to Article 1 Number 22 Law no. 1 of 2004 concerning the State Treasury is a lack of money, securities, and real and definite amount of goods as a result of illegal or negligent acts (Saidi, 2011). This shows that state losses have a very broad meaning so that it is easy to understand if there is a violation in the management of state finances. According to Sumaryanto (2009), it is not a state loss in the sense that it is in the corporate/commercial world, but rather a loss due to an act (an act against the law). The factors that cause state losses are the implementation of improper policies, enriching oneself, others, or corporations.

www.scirj.org

(C) 2020, Scientific Research Journal

http://dx.doi.org/10.31364/SCIRJ/v8.i8.2020.P0820XX

This publication is licensed under Creative Commons Attribution CC BY. 
State financial loss is a lack of real and definite amount of money, securities, and goods as a result of deliberate or negligent unlawful acts. State losses and claims for compensation are substances in state financial law that involve state financial managers and the authorities in charge of claiming compensation when one of the parties is unable to carry out its function, meaning that there are obstacles in enforcing the state finance law. According to Yunus Hussein, state losses are closely related to transactions such as transactions for goods and services, transactions related to accounts payable, and transactions related to expenses and income (Tjandra, 2014).

Sumaryanto (2009) argued that the state loss caused several possible events, namely:

a. There is procurement of goods at prices that are not reasonable because they are far above the market price, to cause losses to the state finances as large as the difference between the purchase price and the market price or at a reasonable price;

b. The price for the procurement of goods and services is reasonable, reasonable but not under the required specifications for goods and services. If the prices of goods and services are cheap but the quality of goods and services is not good, it can be said that they are also detrimental to the state.

c. Some transactions increase the state's debt unnaturally so that it can be said that it is also detrimental to state finances because the state's obligation to pay the debt is getting bigger.

d. Unreasonably reduced state receivables can also be said to be detrimental to the state;

e. State losses can occur when state assets are reduced because they are sold at cheap prices or gifted to other parties or exchanged with private parties or individuals.

f. Increase the costs of the agency or company, this can occur either because of waste or in other ways, such as creating fictitious costs.

g. A company's sales results are reported to be smaller than previous sales.

State losses from the aspect of Law no. 15 of 2004 concerning Audit, Management, and Accountability of State Finances can occur in two stages, namely, at the stage, the funds will enter the state treasury and at the stage, the funds will come out of the state treasury. At this stage the funds will enter the state treasury, losses can occur through; tax conspiracy, conspiracy to fines, conspiracy to recover state losses, and smuggling. Meanwhile, at the stage where the funds will go out of the state treasury, the losses occur due to bribery, corruption, bad credit, implementation of activities that are not under the program and others (Saidi, 2011).

Meanwhile, according to Thedorus M. Tuanakotta cited in Saidi (2011), he divides the five sources of state financial losses as follows:

a. Procurement of goods and services

The form of loss for the procurement of goods and services is paid above the amount it should have.

b. Disposal of assets

The release of assets is the release of state assets or the release of state assets.

c. Utilization of assets

The forms of state financial losses from the use of assets include: 1) The state does not receive adequate compensation according to market prices, and others.

d. Asset placement

Asset placement is an investment or investment from state funds. The state's financial losses occur due to the deliberate placement of these funds in investments that are not balanced with risk-reward.

e. Bad credit

Credit is granted in violation of the credit procedures, whether stipulated by Bank Indonesia or by state-owned enterprises.

www.scirj.org

(C) 2020, Scientific Research Journal

http://dx.doi.org/10.31364/SCIRJ/v8.i8.2020.P0820XX

This publication is licensed under Creative Commons Attribution CC BY. 


\section{RESEARCH METHOD}

This research is normative law research, that is, by using normative case studies in the form of legal behavior products (e.g., reviewing laws). The main point of the study is the law conceptualized as norms or rules that apply in society and become a reference for everyone's behavior. So that normative legal research focuses on the inventory of positive law, legal principles and doctrines, legal findings inconcreto cases, legal systematic, level of synchronization, comparative law, and legal history (Muhammad, 2004).

Based on the explanation above, the authors decided to use normative legal research methods to research and write a discussion of this research as a legal research method. The use of normative research methods in this research and writing effort is based on the suitability of the theory and the research method required by the author.

In legal research, there are several approaches, with this approach the researcher will get information from various aspects regarding the issue that is being tried to find answers. The approach method in this research is the statutory regulation approach. Normative research certainly has to use a statutory approach (Marzuki, 2008). This is because what will be examined are various legal rules that become the focus as well as the central theme of a study. Meanwhile, the data analysis carried out in this study was carried out with a more qualitative approach, namely to reveal as much legal material data as possible so that the issues raised were more transparent. Also, the qualitative approach allows the researcher to elaborate the data obtained comprehensively and the results of the description are more accountable.

\section{RESULTS AND DISCUSSION}

\section{The State Loss Recovery System in Indonesia}

In the case of State losses, we need to know in advance about Information and Verification of State Losses, while information about state losses can be found from:

\section{a. BPK examination.}

The results of the BPK examination are contained in the BPK Audit Results Report (LHP). The LHP is information about state losses.

b. Supervision of functional supervisory apparatus.

Supervision of the government functional/internal supervisory apparatus is carried out by the Inspectorate General of State Ministries/Institutions and the Financial and Development Supervisory Agency (BPKP). If in the implementation of functional supervision it is found/suspected that there is a state loss, the disclosure of the state loss shall be carried out immediately at the first opportunity.

c. Supervision and/or notification of direct supervisors of treasurers or heads of offices/work units.

The head of the institution is obliged to report any state losses to the Minister/Head of Institution and notify the BPK no later than 7 working days after the state loss is known.

\section{d. Ex officio calculations.}

If the Treasurer is negligent in making financial management accountability, is under interception, has fled, or has passed away, and cannot immediately undergo cash testing/examination, then the calculation must be made ex-officio. Calculations made ex-officio are calculations made by other people (not the treasurer in question), namely officials appointed by the head of the local institution. If the calculation is made ex-officio there is a state loss, then the deficiency is the responsibility of the Treasurer concerned (http://www.wikiapbn.org/tata-cara-penyelesaian-ganti-kerugian-negara-terhadap-bendahara/)

Apart from the information above, sources of information on state losses can be obtained from public monitoring/complaints as well as mass media and electronic media. Information on state losses must be managed by each head of the work unit. Each head of the institution is obliged to examine whether the information received is related to the state assets being managed/responsible for. If the information is related to state assets that are managed/under his/her responsibility, then the head of the work unit is obliged to re-examine whether this has met the requirements to be followed up in the context of the process of settling state losses. 
To follow up on the information on state losses, the head of the agency suspected of causing state losses is obliged to form a State Loss Settlement Team (TPKN). TPKN consists of:

a. Secretary- General/head of secretariat of other agencies/regional secretary of province/regency/city as chairman;

b. Inspector General/head of internal control unit/provincial/regency/city inspector as deputy chairman;

c. Head of Bureau/financial department/head of regional financial management body as secretary;

d. Other personnel from work units in the fields of supervision, finance, personnel, law, general affairs and other related fields as members;

e. Secretariat.

The TPKN is tasked with assisting agency leaders in processing the settlement of state losses against the treasurer, whose charges will be determined by the BPK. To carry out these tasks, the TPKN carries out functions to:

a. to take inventory of cases of state losses received;

b. calculate the number of state losses;

c. collect and verify supporting evidence;

d. make an inventory of the assets of the concerned which can be used as a guarantee for the settlement of state losses;

e. settle state losses through SKTJM;

f. provide considerations to the leadership of the agency regarding state losses as material for decision making in determining temporary charges;

g. administer the settlement of state losses;

h. submit a report on the progress of the settlement of state losses to the head of the agency with a copy submitted to the BPK.

If deemed necessary, the head of the institution can form an ad hoc team to settle state losses incurred by the work unit concerned. The ad hoc team collects data/information and verifies state losses based on the assignment of the head of the institution. The head of the institution reports the implementation of the duties of the ad hoc team to the head of the agency concerned with a copy to the TPKN for further processing. Verification is intended to obtain assurance regarding:

a. The amount of state losses;

b. The parties that must be responsible for the loss of the state; and

c. Written evidence that can be justified to support the two things above (http://www.wikiapbn.org/tata-cara-penyelesaian-gantikerugian-negara-terhadap-bendahara/ ).

The results of the research are written in the form of an examination report/examination report/research. The ad hoc team formed has the following duties:

a. collect data, documents, and other evidence and information, consisting of:

1) chronology of state losses;

2) time and place where state losses occur;

3) the identity of the Treasurer who is suspected of causing state losses; and

4) data on state loss objects.

b. perform analysis and verification of data, evidence, and documents as well as other completeness that leads to proving the occurrence of state losses.

www.scirj.org

(C) 2020, Scientific Research Journal

http://dx.doi.org/10.31364/SCIRJ/v8.i8.2020.P0820XX

This publication is licensed under Creative Commons Attribution CC BY. 
c. compile a report on the implementation of duties to the head of the work unit (http://www.wikiapbn.org/tata-cara-penyelesaianganti-kerugian-negara-terhadap-bendahara/).

Reports, Notifications, and Follow-Up on Cases of State Losses:

a. The direct supervisor of the treasurer or the head of the work unit is obliged to report any state losses to the head of the agency and notify the BPK no later than 7 working days after the state loss is known.

b. The notification referred to is completed at least with the document on the Official Report of Cash / Goods Inspection.

c. The form and content of the notification letter to the BPK regarding state losses are made under Attachment I of BPK Regulation Number 3 of 2007.

d. The head of the agency immediately assigned the TPKN to follow up on any cases of state losses no later than 7 days after receiving the report (http://www.wikiapbn.org/tata-cara-penyelesaian-ganti-kerugian-negara-terhadap-bendahara/)

Whereas Reimbursement of State Losses has several ways, while procedures that are carried out outside the judiciary to recover state losses are regulated in the BPK Law and implemented by the financial audit agency. The form of settlement made by the financial audit agency is in the form of claims for compensation relating to state finances which are categorized as state losses. Claims for compensation imposed by the financial audit agency on the parties who have committed unlawful acts in the form of causing losses to state finances(http://jelajahhukumindo.blogspot.com/2017/02/kerugian-negara.html?m=1).

\section{a. Demands for compensation}

The imposition of compensation claims there is two things are interrelated with one another, including imposing sanctions in the form of compensation and the party subject to claims for compensation. The party dropping the claim must not arbitrarily impose a claim for compensation without being based on evidence permitted by the provisions of the applicable laws. Meanwhile, the party who is charged for compensation is obliged to make a payment as a form of compensation for the state when there is sufficient evidence that the person concerned is proven to have done so (Tjandra, 2014).

\section{1) Treasurer}

Treasurers in this scope only focus on different treasurers in the state ministries, non-ministerial institutions, and state agencies. If the treasurer in the management of state finances commits an act of violation of the law or neglects the obligations borne by him and directly causes state losses, he is obliged to compensate for the state loss.

\section{2) Civil servants are not treasurers}

The management of state finances does not always involve the treasurer, sometimes it is carried out by a person as a state employee but not a treasurer so that he is called a civil servant, not a treasurer.

b. Waiver of claims for compensation

Exemption from compensation claims usually occurs if it has met the requirements in the form of the state's right to collect in its expiration state so that the state is not allowed to sue for state compensation. Treasurers, civil servants who are not treasurers and other officials can be exempted from demands for state compensation when the following requirements are met:

1) The right of the state is declared to have expired within five years after the discovery of the loss, not to prosecute for compensation.

2) State rights are declared to expire if, within eight years since the occurrence of losses, the prosecution is not carried out.

3) The right of the state is declared null and void when the competent official does not convey any loss to the state to a treasurer officer, non-treasurer civil servant, or other officials within three years from the court decision stipulating the interdiction.

The procedure for recovering state losses through the judiciary is based on criminal law instruments and civil law instruments, but both contain different procedures to recover state losses due to legal substances that cause differences in the application in the said court.

www.scirj.org

(C) 2020, Scientific Research Journal

http://dx.doi.org/10.31364/SCIRJ/v8.i8.2020.P0820XX

This publication is licensed under Creative Commons Attribution CC BY. 


\section{a. Criminal law instruments}

The criminal law instrument related to recovering state losses through the judiciary is the Corruption Eradication Law. The Corruption Eradication Law contains provisions related to legal actions or actions that cause losses to the state and require appropriate resolution without violating the human rights of parties who are caught as perpetrators of criminal acts of corruption.

\section{b. Administrative law instruments}

In this legal instrument, if there is a state loss committed by a state official or civil servant, personal accountability, criminal responsibility may not be used unless, in the exercise of authority, there is an attempt to enrich oneself, other people or corporations, personal accountability that leads to accountability may be applied criminal.

c. Civil legal instruments

The definition of state finances in civil law, related to the management of separated state assets, is the state assets originating from the state revenue and expenditure budget to be used as state capital participation in private company, public companies, or other limited companies. Recovering state losses through the judiciary may be carried out simultaneously with restitution of state losses outside the court. This is based on the following legal considerations.

1) The recovery of state losses through the judiciary with the restitution of state losses outside the court has a different procedure;

2) State losses returned outside the judiciary are not sanctions or punishments but only compensate for state losses determined by the superiors or the financial audit agency.

3) State losses returned through the judiciary are sanctions or penalties in the form of fines imposed by the court or the corruption eradication commission.

\section{The Role of BPK Audit Results Decisions in Recovering State Losses}

Supreme Audit Agency (BPK) as the Holder of Audit Power. The BPK is in charge of supervising the management of state finances. With this supervision, it is hoped that irregularities will not occur or to avoid practices that result in state losses.

Based on its legal basis, the authority of the BPK has been regulated in Article 23E of the 1945 Constitution, namely to examine the management and responsibility of State finances. Apart from that, in Law Number 15 of 2004 concerning Audit of the Management and Accountability of State Finances, it also emphasizes the duties and powers of the BPK to examine the Government's responsibilities regarding State Finances, to examine all implementation of the State Budget, and to be authorized to request information regarding the tasks it carries out. This is where the BPK plays a role in constantly reporting its audit results to competent institutions to eradicate corruption. The validity of BPK data can be used as preliminary data for law enforcers to carry out investigations into reported indications of corruption. An accurate BPK report will also serve as evidence in court. Evidence of the role of the BPK has a significant influence on the process of prosecuting corruption cases, namely that many legal proces ses will be hampered if the results of the BPK audit are not completed.

The BPK is responsible for checking state finances. The results of the examination are submitted to the People's Representative Council, the Regional Representative Council, and the Regional People's Representative Council under their respective powers. The Supreme Audit Agency examines all implementation of the State Revenue and Expenditure Budget. The examination is carried out based on the provisions in the law.

The audits carried out by the BPK include financial audits, performance checks and we also need to know that the challenges for the BPK in the future will be very complex and varied from the few problems that exist today. Therefore, institutionally BPK RI cannot stand alone without involving the widest possible space for public participation (society). Therefore, the vision of BPR RI going forward must also be based on civil society participation. Currently, BPK RI, apart from not opening public access widely (directly), but also not maximizing the function of coordination with state institutions, particularly law enforcement officials; for example the KPK, Attorney General's Office, PPATK, etc. It is worth criticizing the lack of coordination between state institutions in the context of building a good government system and clean from corruption (clean and good governance), which will complicate things and become an inhibiting factor in realizing this order.

Concretely, the lack of coordination from the outset will hamper the follow-up of the BPK RI audit results, which raises an indication of large state losses (corruption). This should be noted because the BPK does not have the authority in the context of law

www.scirj.org

(C) 2020, Scientific Research Journal

http://dx.doi.org/10.31364/SCIRJ/v8.i8.2020.P0820XX

This publication is licensed under Creative Commons Attribution CC BY. 
enforcement in the downstream sector. And of course, if the results of the BPK audit are not followed up procedurally, then the results of the audit will not have any real impact or benefit, therefore they will end in vain. If this condition occurs, the BPK will be the same as a 'toothless tiger', in which the audit results are not followed up.

In principle, even though in this condition, the BPK cannot be blamed, because actually, BPK RI has carried out its duties and functions as it should have arrived at the stage of exposing the results of the audit carried out, but still BPK did not make a real contribution until the final stage of the follow-up of the results. BPK RI audit. The important point here is that in the future the BPK RI vision must also focus on the aspect of intense coordination with law enforcement agencies in particular so that the audit results from BPK RI are followed up professionally and proportionally.

This means that the BPK's future vision must also focus on the coordination function, which in real terms must be within the executive structure of the BPK RI; possibly apart from the Main Directorate for Planning, Evaluation and Development of State Financial Audit and the Main Directorate for the Development and Development of State Financial Audit Law as stipulated in Article 4 of the BPK RI Decree on the Organization and Work Procedures of BPK Implementers; In the future, it is also necessary to have a special directorate that has orientation and competence in the aspect of coordination, namely the main Directorate for Audit Coordination and Supervision of the BPK.

The BPK must be able to align its functions and authorities with similar institutions or institutions that are identical to the duties and functions of the BPK. In this case, the BPKP and various internal control organizations in various government organizations and departments, such as the Inspectorate General (Inspectorate General), Deputy for Supervision, SPI (Internal Supervising unit), the regional inspectorate or Bawasda (Regional Supervisory Agency, now its name is the Regional Inspectorate).

The results of the BPK examination as mentioned above are the final results of the process of evaluating the truth, compliance, accuracy, credibility and reliability of data/information regarding the management and responsibility of state finances which is carried out independently, objectively and professionally, which is outlined in the audit report as a decision.

BPK members are prohibited from slowing down or failing to report the results of an examination containing criminal elements to the competent authority and if they do, the BPK member concerned will be sentenced to a maximum of 10 (ten) years and/or a fine of at least Rp. 3.000.000.000 (US\$200.000) and a maximum of Rp. 10. 000,000,000.00 (US\$ 667.000).

Concerning the results of the audits conducted by the BPK, BPK should report them to certain parties, including:

a. The BPK submits the results of the examination of the management and accountability of state finances to the DPR, DPD, and DPRD under their authority.

b. For follow-up on the results of the examination, the BPK also submits the results of the examination in writing to the President, Governor, Regent/Mayor under their authority.

c. If a criminal element is found in the examination, the BPK will report the matter to the competent authority under the provisions of the legislation, no later than 1 (one) month after the criminal element is known. What is meant by the authorized agency here is the investigating officer. This BPK report is used as the basis for investigations by authorized investigating officials under statutory regulations.

d. BPK monitors the implementation of follow-up results of audits conducted by the president, governors, regents/mayors and the results are notified in writing to the DPR, DPD and DPRD, as well as the Government.

As we have mentioned above, that the return of state losses that are carried out outside the court is the return of state losses which are regulated in the BPK Law and implemented by the BPK itself. The form of settlement made by BPK is in the form of claims for compensation relating to state finances which are categorized as state losses. The BPK charges for compensation to the parties who commit illegal acts in the form of causing state losses.

In line with the restorative justice theory that we use in this study, that the return of state losses outside the court by making compensation claims carried out by the BPK is more effective in facilitating and accelerating the process of recovering state losses, rather than through a court with a long and winding process. Through this research, researchers want to provide input to further streamline the role of the BPK in recovering state losses outside the judiciary by making compensation claims. So that state financial losses can quickly return.

\section{CONCLUDING NOTES}

www.scirj.org

(C) 2020, Scientific Research Journal

http://dx.doi.org/10.31364/SCIRJ/v8.i8.2020.P0820XX

This publication is licensed under Creative Commons Attribution CC BY. 
Information and verification of state losses are obtained from (1) BPK Audit Report, (2) Supervision of functional supervisory apparatus, (3) Supervision and/or notification of direct supervisor of treasurer or head of office/work unit, and (4) ex officio calculations. Apart from these four sources, information on state losses can be obtained from public monitoring/complaints as well as mass media and electronic media. To follow up information on state losses, the head of the agency is obliged to form a State Loss Settlement Team (TPKN). The TPKN itself consists of the Secretary General, Inspector General, Head of Bureau, Other Personnel from work units in the fields of supervision, finance, personnel, law, general and other related fields as members, and a Secretariat. Apart from the TPKN, the head of the agency can also form an ad hoc team to settle state losses incurred by the work unit concerned. Meanwhile, in recovering state losses, several methods are carried out, (1) demands compensation, through treasurers and civil servants who are not treasurers. (2) waiver of compensation claims. Recovering state losses through the judiciary is based on criminal law instruments, administrative law instruments, and civil law instruments.

BPK as the holder of audit power has the right to supervise the management of state finances. BPK has no authority in the context of law enforcement in the downstream sector. However, in terms of recovering state losses, the BPK has the authority to recover state losses outside the judiciary which are regulated in the BPK Law and implemented by the BPK itself, namely by making claims for compensation against parties who have violated the law in the form of causing state financial losses. In this case, the BPK has a role to make demands for compensation to recover state financial losses.

There are at least two suggestions derived from this study. First, there is a need to strengthening the system for obtaining information and verifying state losses through an online system for each existing agency, and strengthening the system for recovering state financial losses through judicial institutions and also outside the judiciary. Finally, there is a need to make effective and expand the return of state losses by the BPK outside the judiciary by claiming compensation to the parties concerned.

\section{REFERENCES}

Asshiddiqie, Jimly, 2010, Konstitusi dan Konstitusionalisme di Indonesia, Jakarta, Sinar Grafika.

,- 2006, Perkembangan dan Konsolidasi Lembaga Negara pasca Reformasi, Jakarta, Sekretariat Jenderal dan Kepaniteraan Mahkamah Konstitusi.

Badan Pemeriksa Keuangan, 2006. UU RI No. 15 Tahun 2006 tentang Badan Pemeriksa Keuangan, arsip Dhendianto, Biro Hukum BPK RI; 11/3/2006.

Effendy, Marwan, 2005, Penerapan Perluasan Ajaran Melawan Hukum dalam Undang-Undang Tindak Pidana Korupsi (Kajian Putusan No.135/Pid/B/2004/PN.Cn. dan Putusan Sela No. 343/Pid.B/2004/PN.Bgr) , Jakarta : Dictum.

Kementerian Dalam Negeri, 1998. Peraturan Menteri Dalam Negeri Nomor 5 Tahun 1997,

http://www.kejari-jakbar.go.id/index.php/component/k2/item/236-permasalahan-seputar-kerugian-keuangan-negara-tinjauan-dariperspektif-pembuktian-hukum-pidana accessed on February 16, 2020.

http://rodlial.blogspot.com/2014/02/makalah-tentang-badan-pemeriksa-keuangan.html?m=1 accessed on February 16, 2020.

http://tongsel.blogspot.com/2016/03/makalah-keuangan-negara.html?m=1, accessed on February 16, 2020.

http://makalah-titi3.blogspot.com/2017/03/keuangan-negara.html?m=1 accessed on February 16, 2020.

http://www.wikiapbn.org/tata-cara-penyelesaian-ganti-kerugian-negara-terhadap-bendahara/ accessed on February 16, 2020.

http://jelajahhukumindo.blogspot.com/2017/02/kerugian-negara.html?m=1 accessed on February 16, 2020.

Kementerian Dalam Negeri, 1998. Peraturan Menteri Dalam Negeri Nomor 5 Tahun 1997. Jakarta.

Marshall, Tony, 1999, Restorative Justice: an Overview, London, Home Office Research Development and Statistic Directorate.

Marzuki, Peter Mahmud. 2008, Penelitian Hukum. Cet2. Jakarta: Kencana.

www.scirj.org

(C) 2020, Scientific Research Journal

http://dx.doi.org/10.31364/SCIRJ/v8.i8.2020.P0820XX

This publication is licensed under Creative Commons Attribution CC BY. 
Muhammad, Abdul kadir. 2004. Hukum dan Penelitian Hukum.Cet. 1. Bandung: PT. Citra Aditya Bakti.

Paeh, Karel Antonius, Pengembalian Kerugian Negara Berdasarkan Rekomendasi Badan Pemeriksa Keuangan (BPK) Hubungan Dengan Unsur Kerugian Negara Dalam Tindak Pidana Korupsi, e Jurnal Katalogis, Volume 5 Nomor 2 Februari 2017.

Saidi, Muhamamad Djafar, 2011, Hukum Keuangan Negara, Jakarta, Raja Grafindo Persada.

Sidjabat ,W. Bonar, 1968, Partisipasi Kristen dalam Nation Building di Indonesia, Jakarta, Badan Penerbit Kristen.

Sriwidodo, Joko, 2014, Penerapan Mediasi Tindak Pidana Kekerasan Dalam Rumah Tangga Berdasarkan Restorative Justice Dalam Distem Peradilan Pidana di Indonesia, Yogyakarta, Penerbit Kepel Press.

Sulaiman, Anwar, Manajemen Aset Daerah, Jakarta, STIA LAN Press, 2000.

Sumaryanto, A. Djoko, 2009, Pembalikan Beban Pembuktian: Tindak Pidana Korupsi Dalam Rangka Pengembalian Kerugian Keuangan Negara, Jakarta, Prestasi Pustaka Publisher.

Persada.

Tjandra, Riawan, 2014, Hukum Keuangan Negara, Jakarta, Gramedia.

Yani, Ahmad, 2004, Hubungan Keuangan Antara Pemerintah Pusat Dan Daerah Di Indonesia, Jakarta, Raja Grafindo Persada. 